\title{
When ends Trump means: continuity versus change in US counterterrorism policy
}

\author{
Rubrick Biegon and Tom F. A. Watts
}

Global Affairs

Author Accepted Manuscript for Kent Academic Repository (KAR)

DOI: https://doi.org/10.1080/23340460.2020.1734956

\begin{abstract}
This article utilizes a historical materialist informed framework to analyse change and continuity in US counterterrorism policy. Although Donald Trump's “America First” discourse conveyed a "new" approach to counterterrorism, in practice his administration has largely reinforced pre-existing tendencies, expanding the military campaigns against ISIS and al-Qaeda. In accordance with America's longstanding objectives in the global south, which centre on stabilizing existing patterns of capitalist political-economic relations, the US continues to police transnational security challenges "from below". The article calls for increased sensitivity to the means-ends calculus in American statecraft. It argues that tactical shifts at the policy level (the means) should be situated in relation to historical considerations and the structural and material factors (the ends) that impact US foreign policymaking across presidential administrations.
\end{abstract}

\section{ARTICLE HISTORY}

Received 29 October 2019

Accepted 23 February 2020

KEYWORDS

US foreign policy; Trump; counterterrorism; historical materialism; continuity 


\section{Introduction}

The study of Donald Trump's foreign policy has been closely associated with the president's bombast and sloganeering. On the subject of counterterrorism, ${ }^{1}$ his virulent rhetoric has conveyed the sense of a fundamental discontinuity in the military response to transnational terrorist organisations. In place of his predecessor's targeted war against al-Qaeda and its affiliates, Trump offered an existential struggle to "eradicate" what he terms "Radical Islamic Terrorism" (Trump, 2017). Reinforcing perceptions of change, the 2018 National Strategy for Counterterrorism repeatedly referenced the pursuit of a "new approach" to counterterrorism (The White House, 2018). This article adopts a historical materialist informed framework to challenge this narrative. We argue that there has been an underlying continuity in the practices and logic of the Trump administration's military response to transnational terrorist organisations. This reflects established counterterrorism policy and the system-management role the US plays in the international capitalist order.

Consistent with his rhetoric, Trump escalated existing campaigns against ISIS and al-Qaeda. Yet, the underlying trend has been more evolutionary than revolutionary. Far from tearing up his predecessor's "remote" counterterrorism playbook, the Trump administration has embraced it. There have been more drone strikes, more Special Operation Forces (SOF) raids, and a continued reliance on security cooperation. Trump neither pioneered these practices, nor has he wound down the global military response against transnational terrorist organisations. Additionally, as we argue, the administration's insistence that "inter-state strategic competition, not terrorism, is now the primary concern in U.S. national security" (Mattis, 2018, p. 1) has reinforced, rather than departed from, pre-existing strategic goals. Notwithstanding the challenge to the "liberal capitalist international order" (Bromley, 2006, p. 4) brought about 
by China's rise, the Trump administration has remained committed to reproducing American primary within it.

Tactical shifts in the means of Trump's counterterrorism policy should be situated in relation to the structural ends of American imperialism. These structural imperatives are key to categorising the extent of policy change because, in contrast to the elasticity of counterterrorism discourse and tactics, they have proven remarkably durable, limiting the agential capacity of the Trump administration to radically realign US policy in accordance with an "America First" ideology. We argue that counterterrorism has continued to perform two key strategic functions during Trump's presidency: defending the reproduction of open-door access to overseas markets, resources, and labour and, by extension, entrenching US structural power in international relations.

Much of the existing debate on continuity and change in Trump's foreign policy has focused on Trump's transactional approach to post-war security partnerships, rules-based international trade, and multinational institutions. Trump's counterterrorism policies, in contrast, have been subject to less scrutiny. Whilst empirically rich, existing studies have been light on theory, focusing mainly on the tactical shifts in, and the policy implications of, the military response to al-Qaeda and the Islamic State (Brands \& Feaver, 2017; Kraft \& Marks, 2017, pp. 109-122; Starr-Deelen, 2017). This is problematic for two reasons. First, like Japanese knotweed, counterterrorism has warped much of American foreign policy since the 9/11 attacks (Malley \& Finer, 2018). Its study can therefore tell us much about the change/continuity problematic in Trump's wider foreign policy. Second, whilst tactical changes in Trump's counterterrorism policy are important, existing studies don't address the larger question of why the administration maintains the costly military response to transnational terrorist organisations- 
a puzzle given Trump's calls for a more transactional, "America First" approach to foreign policy. This article addressees these gaps by drawing on the historical materialist informed literature on contemporary American foreign policy and military intervention in the global south (Blakeley, 2018; Bromley, 2006; Gowan, 2006; Stokes, 2005, 2009; Stokes \& Raphael, 2010; Thomson, 2018). Underutilised in the study of American foreign policy after George W. Bush's presidency, it adds to this Special Issue's theory-driven examination of change/continuity in the Trump presidency by advancing an alternative political-economy account of the structural barriers to transformative change (Ashbee \& Hurst, this volume).

As we argue, Trump's interventionist counterterrorism posture, detailed below, coheres with the policies of the Bush and Obama administrations. Modifications in the means of policy, as seen at the tactical level, reinforce strategic and structural ends that are largely unchanged in the longer trajectory of post-9/11 statecraft. In foregrounding the notion of a means-ends calculus in debates on change and continuity, we advocate greater sensitivity to the ways in which shifts in policy are subsumed to more deeply-rooted objectives that, in foreign policy terms, tend to outlast specific presidential administrations. ${ }^{2}$ This article aims to refresh earlier debates on the continuities in US foreign policy (see for example, Kolko, 1988) by extending political-economic considerations to the particularities of the Trump presidency, the emergence of more "remote" modalities of American military intervention (Watts \& Biegon, 2017), and US counterterrorism strategy in an age of renewed great power competition.

We begin by outlining the theoretical framework that informs our examination of US counterterrorism strategy. This foregrounds the structural factors that shape US counterterrorism efforts and mitigate against a fundamental realignment of objectives. In acknowledging Trump's discursive development of an "America First" agenda, we then argue 
that, whilst the administration has accelerated the "militarisation" of US counterterrorism practices, it has largely reinforced pre-existing tendencies. In accordance with Washington's longstanding objectives in the global south, which centre on stabilising existing patterns of capitalist political-economic relations, we detail the ways in which the US continues to police non-state security challenges "from below." Increasingly, however, concerns over transnational terrorism are giving way to a renewed focus on "revisionist" states, namely China. As we discuss, this blending of state and non-state security challenges tightens Washington's existing interventionist posture in the global south, and cannot be reduced to Trump and/or his "America First" agenda.

\section{A historical materialist informed approach to Trump's counterterrorism policy}

Disappointing those who anticipated a radical realignment of American counterterrorism policy, Obama pursued an evolutionary rather than revolutionary approach to counterterrorism (Jackson, 2011; Quinn, 2011). This continuity has been explained in multiple ways. For some, it was the result of the War on Terror's institutionalisation as a discursive "regime of truth" which "locked in" certain narratives, policies, and bureaucratic assemblages (Jackson, 2011). For others, it was shaped by the interplay of US relative decline and Obama's proclivity for more constrained approaches to the use of force (Quinn, 2011). Domestic politics inform this continuity, with military operations against transnational terrorist organisations being viewed as "the area of greatest bipartisan consensus" in an age of deepening polarisation (Malley \& Finer, 2018, p. 59). Although historical materialist contributions sharpened the debate over "empire" in the George W. Bush era (Bromley, 2006; Gowan, 2006; Stokes, 2005), recent developments in US counterterrorism policy have not been subject to the same kind of critical analysis. 
When approached as a social science, historical materialism advances a more holistic understanding of "the international" by positioning "the political and economic as mutually constitutive" rather than as spheres to be analysed separately (Herring \& Stokes, 2011, p. 13). ${ }^{3}$ Historical materialist approaches are historical in their sensitivity toward the "indispensability of the empirical" and the importance of situating their analysis within the specific epoch of capitalist globalisation. They are materialist in their non-reductionist focus on the role of class and production in the evolution of social relations within and between states (Herring, 2013, pp. 45-46). The imprint of canonical thinkers such as Marx, Engels, and Lenin, among others, on contemporary debates on American foreign policy is uneven. Some have drawn from Robert Cox's (1981) Gramscian work on hegemony to explore the role of both coercion and consent in the globalisation of capitalism (Biegon, 2017; Robinson, 1996), ${ }^{4}$ while Kautsky’s concept of "ultra-imperialism" has more recently inspired critical readings of Washington's management of the liberal international order and the place of elite networks therein (Huo \& Parmar, 2019; Parmar, 2018). These cleavages speak to richness of historical materialism as a social science tradition, but they also point to the challenges in applying it to discrete issues in international relations. Although historical materialists offer different theorisations of the changing relationship between capital, resistance, and power in world politics, they are united in an understanding that "political" and "economic" phenomena cannot be entirely separated from one another.

This is not to imply that crude economic interests serve as a causal "transmission belt" to specific foreign policy outcomes. There is necessarily some "distance" between the imperatives of imperialism and the contingencies expressed in Trump's counterterrorism policies. The aim of historical materialist informed study of contemporary American foreign policy is to unravel 
the "[i]nterplay between state power, capitalist elite interests and the use of disciplinary state violence from above" (Blakeley, 2018, p. 323). This involves tracing the continuities in the goals, if not pretexts, of US interventionism across time, whilst remaining sensitive to the economic and strategic animators of such activities (Blakeley 2018; Stokes \& Raphael, 2010; Thomson, 2018). The US has defended, deepened and, where possible, extended privileged access to overseas markets, resources, and labour. The maintenance of a stable investment and extraction climate, particularly in oil rich areas (Stokes \& Raphael, 2010; Wearing, 2018), has been key to the reproduction of American primacy. To this end, the US has policed attempts by oppositional social forces — whether these have been nationalist, communist, or Islamist in orientation - to carve out zones of exclusion from the circuits of transnational capital, often reordering the political and social relations of other states to facilitate this process. This scholarship therefore challenges the notion of a fully "liberal" order. Although US power has been exercised through multilateral rules and institutions in the capitalist core of Western Europe, Japan and Australasia, in much of the global south "American involvement has often been crudely imperial" (Ikenberry, 2011, p.27).

Supported by capitalist powers such as Great Britain, which has performed a key constabulary role in the Middle East (Wearing, 2018), the US has employed multiple forms of coercive statecraft to maintain stability in strategically important areas of the global south (Blakeley, 2018). Given the informal configuration of post war American imperialism through states organised to be conducive to US interests, "polyarchic" forms of "low-intensity democracy" have been widely promoted (Robinson, 1996). During the Cold War, repressive right-wing regimes were supported as bulwarks against instability and Soviet influence (Kolko, 1988). In the 2000s and 2010s, under the guise of counterterrorism, the US continued spending billions of dollars training and equipping overseas security and paramilitary forces (Stokes \& Raphael, 
2010; Thomson, 2018). Much of this assistance has been used to build the counterinsurgency capacity of states to police subversion within their borders, thereby insulating governments amicable to American interests. By "armouring" the flow of oil and other commodities onto global markets, the US has stabilised existing political economies in a manner that benefitted not only domestic elites, but the longer-term interests of key factions of US-based transnational capital (Stokes \& Raphael, 2010).

The defence of stable access to overseas markets, resources, and labour, historical materialist informed scholars speaks to a second core logic of contemporary American counterterrorism policy: reinforcing the US's structurally dominant position within what Bromley has dubbed the "liberal imperialist international capitalist order" (Bromley, 2006; see also Gowan, 2006; Thomson, 2018, p. 22). As a construct for organising foreign policy, the War on Terror aimed to "lock in" US primacy. Maintaining global energy security, for example, is not only intended to meet the American economy's energy needs. It also has geopolitical functions. The US gains structural leverage over rival nodes of capitalist accumulation-Western Europe, North America and South Asia-because of their reliance on the US's provision of this international public good (Stokes \& Raphael, 2010, pp. 1-2; Wearing, 2018, pp. 58-59). The "shale gas revolution," which in recent years has driven the US's re-emergence as a leading oil exporter, has not undercut this policing role. As Gilbert Achcar argues:

[c]ontrolling access to oil, especially the biggest reserves in the Arab-Iranian Gulf, gives the United States a decisive strategic advantage in the battle for world hegemony, putting it in a position of dominance vis-à-vis both its greater potential rival, China, and also its traditional vassals, Western Europe and Japan, all heavily dependent on oil imports from the region (quoted in Wearing, 2018, p. 9). 
In an era of heightened greater power competition, energy-sector leverage provides structural power. As such, the military response to transnational terrorist organisations can be read as a vehicle for policing challenges to American imperialism from below-in the case of transnational terrorist organisations like al-Qaeda and the Islamic State-and above-in the case of China, slated to become the world's largest oil importer in the very near future (Wearing, 2018, p. 57).

By emphasising class-based interests and economic factors within and across international borders, historical materialism relates changing patterns of imperialist intervention to powershifts in international politics. During the early period of the War on Terror, a more aggressive US security strategy coincided, somewhat paradoxically, with an easing of great power rivalry. This lead some analysts to evoke the "ultra-imperialism" first theorised by Karl Kautsky, recast as "super-imperialism" in more recent scholarship (Bromley, 2006; Huo \& Parmar 2019; Parmar, 2018). In this view, US hegemony allows for "coordinated power in a liberal capitalist international order" (Bromley, 2006, p. 49). The imperial pursuit of "open doors and closed frontiers," in Colás' phrasing (2008), reproduces class alliances across global power-centres. Transnational elite networks are consolidated through the "liberal international order," backed by US power (Huo \& Parmar 2019; Parmar, 2018). The promotion of capitalist market relations based on the stability of the inter-state system becomes, to an extent, a shared project under US geopolitical leadership, but creates the conditions for centripetal resistance through the active promotion of "competing centres of political authority and wealth accumulation" (Colás, 2008, p.620). 
Acknowledging divisions within the historical materialist literature in IR, our grounding within this critical tradition allows us to make three key contributions to debates on the Trump presidency.

First, a historical materialist foundation encourages us to study Trump's counterterrorism policies as part of a larger series of historical processes which fully began with the ascent of American hegemony after 1945, but which has roots in the long durée of North-South relations formed during the age of European colonialism (Blakeley, 2009). As Wearing argues, "[t]he decisions made by individual politicians at specific times are important but must ultimately be understood within these wider structural contexts" (2018, p. 3). To this end, historical materialists reject the "discontinuity" thesis which holds that either the collapse of the Soviet Union and/or the 9/11 attacks precipitated fundamental changes in American foreign policy. The contingencies captured in the post-9/11 military response to transnational terrorist organisations are read within the structural realities of the evolving relationship between American power, imperialism, and the international order established in 1945. This commitment to historicising Trump's counterterrorism policy strengthens the debate on continuity and change. A longer-term view avoids the parochialism that magnifies tactical and discursive differences, creating unwarranted perceptions of "newness" when comparing Trump to Bush and Obama.

Second, by capturing the "structural processes at work in the post war global political and economic system" (Stokes \& Raphael, 2010, p. 10), an historical materialist informed approach can broaden the debate on counterterrorism policy beyond "certain hegemonic discourses" (Stokes, 2009, p. 88), which present US actions as serving clear-cut "national security" objectives. The system-management role that Washington plays in the global economy has 
privileged the US as the key "mediator" between the established order and revisionist powers. In this regard, the US has not only retained the capacity to define threats to international security, but to outline the appropriate response (Stokes, 2009, p. 86). We aim to "relate these discursive practices to sustained analysis of the class and other interests and social relations within capitalism" (Herring \& Stokes, 2011, p. 13) This focuses our analysis on the more durable practices and interests of the American state, rather than the more elastic discursive and cultural grammars which are used to "sell" these to domestic and international audiences, discussed elsewhere in this Special Issue (see Fermor \& Holland; Hassan).

And third, historical materialist perspectives on American foreign policy advance an alternative, political economy focused account of the structural barriers to a radical break in counterterrorism policy. When situated within the longue durée of North-South relations (Blakeley, 2009), the challenges associated with transnational terrorist organisations like alQaeda and ISIS involve more than "national security," narrowly defined. These groups also undermine the wider primacy of the American state by threatening to destabilise key areas of the global economy, particularly the Middle East (Blakeley, 2018, p. 327). In the case of global energy security, al-Qaeda affiliates such as al-Qaeda in the Arabian Peninsula and the Islamic State have attempted to disrupt American access to Middle Eastern oil and gas reserves (Tichy \& Eichler, 2017). By capturing territory and threatening stable governance, these groups disrupt the integration of fragile states into the US-led global capitalist order. Through these actions, transnational terrorist organisations undermine a core pillar of the US structural power over rival centres of capitalist accumulation, most notably China. In this respect, historical materialist approaches capture the often neglected political-economy drivers of US counterterrorism-as-foreign-policy: the hegemonic imperative of defending open-door access 
to markets, resources, and labor in the global south through covert warfare and the augmentation of internal security practices of partnering states.

\section{An "America First" approach to counterterrorism?}

Trump has dramatically changed the discourse of US counterterrorism policy. Whereas Obama sought to roll back the Bush administration's expansive War on Terror discourse, Trump's bellicosity serves as a rejection of Obama's restraint. While running for office, Trump pledged to radically reorient US counterterrorism policy. Criticising the Obama administration's "politically correct" approach, he claimed the "rise of ISIS" was the "direct result of policy decisions made by President Obama and Secretary Clinton” (Trump, 2016a). In November 2015, Trump outlined his "plan" for defeating the Islamic State, which, following its swift territorial conquests in Iraq and Syria, had surpassed al-Qaeda as the principal terrorist threat for policymakers in Washington. Given the "tremendous amount of money" ISIS was making from oil sales, Trump said he "would bomb the shit out of them." (quoted in Hains, 2015). In April 2016, Trump proposed plundering Iraq's oil to reimburse American taxpayers for earlier occupations. "In the old days," he stated, "when we won a war, to the victor belonged the spoils. Instead, all we got from Iraq — and our adventures in the Middle East—was death, destruction and tremendous financial loss" (Trump, 2016a). Despite opposition from some administrational officials, whilst in office, Trump institutionalised the controversial term "Radical Islamic Terrorism" (Kraft \& Marks, 2017, p. 112), as referenced in the 2018 National Strategy for Counterterrorism (The White House, 2018).

Discursively, Trump's “America First” foreign policy intimates a more "muscular" use of military power to combat ISIS and al-Qaeda. This coexists with the notion that, in putting 
America first, the US must avoid being "taken advantage of" in its counterterrorism commitments, whether by allies, international organisations or adversaries. Engendering concerns about the durability of the Washington's commitment to its NATO and East Asian partners, Trump stated in 2016: "Our allies must contribute toward their financial, political, and human costs, have to do it, of our tremendous security burden (sic)... The countries we are defending must pay for the cost of this defense," he added, "and if not, the US must be prepared to let these countries defend themselves" (Trump, 2016b). The "America First" frame is designed to project an image of an unabashed nationalism, conveying the sense of a clear break with the internationalism (or "globalism") of recent administrations. Beyond this rhetorical break lies a more nuanced reality, often obscured in Trump's personalised political style. As outlined below, policy is not reducible to the statements or political posturing of the commander-in-chief.

As argued in the historical materialist literature (Stokes, 2009; Stokes \& Herring, 2011), the instrumentalist language of political elites emerges out of ideological commitments, with the discursive sphere existing in dialectical relation to material and structural factors. From this view, "America First" is not "mere rhetoric," but a pledge that must be adequately contextualised. This means examining the rhetorical and tactical shifts alongside deeper structural objectives. With respect to the "ends" of US foreign policy, although the notion of "America First" is intensely illiberal in some respects, it is not "isolationist." The Trump administration remains committed to hegemony (Biegon, 2019), even as it seeks a new and ostensibly less burdensome arrangement within the existing order. Despite Trump's eccentricities, his administration's approach to statecraft blends security and economic interests and objectives in a relatively traditional manner. As we discuss in the next section, in seeking tactical change in response to transnational violence from below, US counterterrorism 
policy continues to service a larger imperial agenda. In the subsequent section, we examine the implications of the renewed focus on rogue and revisionist states for US interventionism. The discussion illustrates that, notwithstanding rhetorical and tactical shifts, the Trump administration has maintained a means-ends calculus that is consistent with previous post-9/11 administrations, and which is consistent with the system-management role played by the US in the post-war international order.

\section{The evolving military response to transnational terrorist groups}

In rhetorical and strategic terms, Obama outlined an end the "permanent war" associated with the Bush administration's "Global War on Terror" (Kitchen, 2016). Even so, his administration institutionalised many of Bush's (second-term) modifications in counterterrorism policy. Relying on a set of more "remote" practices of military intervention throughout the Middle East and Africa, the Obama administration pursued a lighter-footprint approach (Krieg, 2016; Watts \& Biegon, 2017). The most controversial of these practices was the widespread use of drones to conduct reconnaissance operations and carry out targeted strikes against militant leaders, supported by Special Operations Forces (SOF) deployments and "train-and-equip" programs (Tankel, 2018b; Watts \& Biegon, 2017). Throughout the Middle East and Africa, the Trump administration has intensified the use of multiple methods of more remote intervention to "defeat the terrorists who threaten America's safety, prevent future attacks, and protect our national interests" (The White House, 2018, p. ii). When situated within the structural contexts and historical role performed by the American state in the international capitalist order, this emphasis on "national interests" alludes to the political-economy functions of counterterrorism. 
Although the form of US imperialism may be in flux, the structural realities of US interests create continuity in Washington's commitment to coercive statecraft. In historical materialist scholarship, this provides a baseline for analysing US foreign policy in the global south. Whether embedded in an "ultra" or "inter" imperialist logic, the United States projects military power to protect the reproduction of capital when and where threats emerge, but in a manner that is also designed to secure American primacy (Stokes \& Raphael, 2010). This entails the use of "disciplinary violence from above" to "police" threats to sectoral and systemic economic interests (Blakeley, 2018, p. 323; see also Colás, 2008; Stokes, 2005). Because of the flexibility associated with Washington's military advantages, the "tools" that constitute this policing role may vary, from drones to proxies to Special Forces (Blakeley, 2018; Thomson, 2018), even as the "ends" remain relatively stable. Whether targeting transnational terrorist organisations or rival states, the modalities of US imperialism mitigate against a wholesale retrenchment of the kind that some observers associate with Trumpian nationalism.

In big picture terms Trump, like Obama, has rejected the logic of open-ended, large-scale military campaigns, a major source of continuity across the two administrations. As Trump puts it: "We are not nation-building again. We are killing terrorists" (Trump, 2017). The administration has intensified the turn toward "remote" practices of military intervention, loosening the various constraints on the use of force that the Trump team associated with Obama (Fielding-Smith \& Purkiss, 2018). According to Jon Finer (2019, p. 188), who served under Obama, the presence of hawkish advisors within the administration overran the president's noninterventionist instincts, fostering the escalation of military involvement in all of the major counterterrorism campaigns which Trump inherited: Afghanistan, Iraq, Libya, Niger, Syria, and Yemen. These actions have accelerated the militarisation of American foreign 
policy, raising renewed concerns regarding the oversight and human costs of counterterrorism (Kraft \& Marks, 2017, p. 117; Starr-Deelen, 2017).

Trump has significantly expanded the use of armed drones for targeted killing increasing both the strike quantity and geographic scope of these activities. As a flexible means of "imperial policing through air power" (Blakeley, 2018, p. 327), drone attacks have become a mainstay of Washington's "unconventional” warfighting capabilities. While the Obama administration designated Afghanistan, Iraq, Syria, and parts of Libya as "areas of active hostilities," Trump added Yemen, Somalia, Pakistan, and the entirety of Libya to the list, giving the US recourse to quicker turn-around times to carry out drone strikes (Malone, 2018, pp. 6-7). In Somalia, for example, the Trump administration escalated airstrikes against al-Shabaab in 2018 and 2019, with strikes targeting larger groups of suspected fighters. This was facilitated by the loosening of Obama-era constraints on the use of force in Somalia, as well as the drawdown of US military operations elsewhere (namely Syria and, to a lesser extent, Afghanistan), which freed up drones and other resources (Schmitt \& Savage, 2019). US drone and air strikes in Yemen also increased considerably in Trump's first year in office (from 32 in 2016 to 131 in 2017), before declining to Obama-era levels (36 strikes) in 2018 (Johnsen, 2019). In January 2020, a Reaper drone was used to kill the Iranian General Qasem Soleimani at Baghdad International Airport in what the Trump administration described as "time sensitive targeting" against a “target of opportunity” (Capaccio, 2020).

Like Obama, Trump has relied heavily on SOF, including the Defense Department's Joint Special Operation Command (JSOC) which was responsible for the October 2019 raid which killed the ISIS leader Abu Bakr al-Baghdadi. In his first week in office, Trump authorised a high-profile SOF raid against al-Qaeda in the Arabian Peninsula based in Southern Yemen, 
resulting in the death of a Navy SEAL and a number of civilian causalities (Mcfadden, Arkin, \& Uehlinger, 2017). In May 2017, a Navy SEAL was killed in a raid against al-Shabaab-the first US combat death in Somalia since the 1993 Black Hawk Down incident (Cooper, Savage, \& Schmitt, 2017). During Trump's first year as president, SOF were deployed to at least 137 countries (Turse, 2017). The expanded use of SOF led one analyst to argue that Trump was “pushing America’s Special Forces past the breaking point” (Zenko, 2017).

Additionally, military assistance has remained a key tool in Trump's counterterrorism arsenal. As the 2018 National Counterterrorism Strategy emphasised, "augment[ing] the capabilities of key foreign partners to conduct critical counterterrorism activities" remains an essential component of the military response to transnational terrorist organisations (The White House, 2018, p. 23). According to figures compiled by the Security Assistance Monitor, the administration requested a total of $\$ 11.2$ billion in counterterrorism aid in FY 2019 (Goodman \& Arabia, 2018). Whilst there have been considerable cuts to State Department-funded security assistance programmes during Trump's presidency, in the case of counterterrorism initiatives, these have been largely offset by an uplift in DOD-funded programmes (Goodman \& Arabia, 2018). Military assistance has been integral to Washington's support for local partners tasked with maintaining the stability of key areas of the global economy against challenges from counterhegemonic social forces (Stokes \& Raphael, 2010, pp. 56-64).

Conceivably, Trump could have ended campaigns against transnational groups which only peripherally or indirectly threaten US national security. To put America first in a manner consistent with the transactional, quasi-isolationist tone of his campaign rhetoric would have suggested that he disengage from some of the US's security commitments in the global south. Despite Trump's rhetorical overtures toward retrenchment, and notwithstanding minor 
modifications to US strategic doctrine, this has not happened. Consistent with our historical materialist framework, the Trump administration has continued to police transnational terrorist organisations, even if the policy is sometimes at odds with Trump's claims.

The confusion surrounding US policy toward Syria is indicative of this. In early 2018, thenSecretary of State Tillerson stated that the US would "maintain a military presence in Syria focused on ensuring ISIS cannot remerge," a move that kept intact the basis of Obama's ISIS policy (Goldenberg \& Heras, 2018). In December 2018, Trump indicated that he was planning on pulling all US troops out of Syria, only to reverse course in early 2019 , with a decision to leave a contingent in the country. Similar events transpired in the autumn of 2019. In the context of the impeachment inquiry by Congressional Democrats, Trump announced he would remove US troops from northern Syria. Criticising "endless wars," Trump hinted at a full military withdrawal from the country, but the administration later clarified it was planning on leaving several hundred troops in Syria to "protect the oil fields" (Ward, 2019).

A similar dynamic can be seen with respect to Afghanistan, where US-led combat operations officially ended in 2014. Trump agreed to the reintroduction of over 3,000 troops in 2017, despite his longstanding views in favour of “pulling out.” In September 2019, Trump revealed that he had been pursuing secret negotiations with the Taliban before abruptly cancelling meetings with its representatives. The appropriate "balance" or degree of US involvement in Afghanistan, as in Iraq and Syria, continues to be debated in Washington, but it is clear that the Trump administration has not implemented a "break" in US policy towards these major "hotspots." Rather, he has effectively widened the scope of existing campaigns against ISIS, al-Qaeda and their various affiliates, augmenting Washington's imperial policing role in a region of continued geopolitical importance. 
Under Trump, the United States has continued to use a blend of kinetic and non-kinetic counterterrorism "tools," most illustratively demonstrated in the military response to ISIS. Initially, the Trump administration claimed it would deploy up to 30,000 American troops in the Middle East to "knock out ISIS" (Nussbaum, 2016). This did not happen. Instead, it persisted with a modified form of the "medium-footprint" approach pioneered under Obama: "an aggressive campaign encompassing air strikes, drone attacks, special operations raids, and small deployments of regular ground troops in response to specific threats, all in support of efforts by regional US partners" (Brands \& Feaver, 2017, p. 28). Substantive operational changes were minimal (Dombrowski \& Reich, 2018, p. 65). It continued to appropriate substantial funds to Iraqi Security Forces via the Counter-Islamic State in Iraq and Syria Train and Equip Fund, with \$1.27 billion in FY 2018 and \$0.85 billion in FY 2019 (Security Assistance Monitor, 2019). At the same time, with respect to Syria, "the Trump administration instituted a policy shift by loosening the rules of engagement to allow larger and more risky strikes" (Dombrowski \& Reich, 2018, p. 64). As the operational strategy was delegated to military commanders, the reported number civilian deaths from coalition strikes in Iraq and Syria jumped significantly in the first year of Trump's presidency, before settling again in 2018 and 2019.

Why have these campaigns continued? According to the 2017 National Security Strategy (NSS): "Changes in a regional balance of power can have global consequences and threaten U.S. interests. Markets, raw materials, lines of communication, and human capital are located within, or move among, key regions of the world" (emphasis added: The White House, 2017, p. 45). For the Trump administration, American interests are threatened by the closure of opendoor access to markets, resources and labour in key regions, such as the Middle East. Speaking 
to the longer-term strategic benefits of combatting al-Qaeda and ISIS, as the NSS continued: "States that prosper and nations that transition from recipients of development assistance to trading partners offer economic opportunities for American businesses. And stability reduces threats that target Americans at home" (The White House, 2017, p. 45). In other words, and consistent with our historical materialist framework, by intensifying the campaigns against the disruptive non-state violence of al-Qaeda and the Islamic State, the Trump administration is, according to its own strategic logic, working to stabilise key areas of the global economy. In this respect, tactical changes are subsumed to a fundamental continuity in structural objectives.

\section{Counterterrorism in an age of renewed great power competition}

Ongoing power shifts suggest the character of US imperialism is being challenged. "As superimperialist leadership is eroded," wrote Bromley in the wake of the Iraq war, "so interimperialist emulation and rivalry beckon" (2006, p. 46). China's rise is the most important development in this regard, as it indicates the presence of a near-peer strategic competitor. Although future conflict between the US and China is not inevitable, increased competition between major powers seems to be a core feature of the current interregnum (Babic, 2020; Parmar, 2018; Huo \& Parmar, 2019). The tensions latent in the ultra-imperialism of the early War of Terror era have come firmly to fore, placing considerable strain on the managerial capacity of the American state to maintain its primacy in the global economic and political order it created after 1945. The Trump administration's “America First" approach, which aims to reduce US commitments to the liberal international order, aggravates these uncertainties (Parmar, 2018, p. 152). The shift toward a more competitive configuration of imperial power has implications for wider US security strategy, as evidenced by the new focus on state-based threats in US counterterrorism doctrine, discussed below. 
Following its release in October 2018, analysts expressed "relief" at the "mainstream" approach outlined in the Trump administration's National Strategy for Counterterrorism (Geltzer, 2018; Tankel, 2018a). There were some tactical readjustments, including a renewed focus on the importance of "building strong borders" (The White House, 2018, p. 1). Nonetheless, the strategy eschewed Trump's divisive rhetoric "while embracing the institutional memory and best practices built up under his predecessor" (Geltzer, 2018). Given the disparity between Trump's public comments and the document, some questioned whether the president was actually aware of its contents (Tankel, 2018a). The strategy's definition of an "America First" approach was relatively traditional: it would be "guided by United States interests; shaped by realistic assessments of both our challenges and our capabilities; and attuned to the important roles of our allies and partners, both foreign and domestic, in our shared counterterrorism efforts" (The White House, 2018, p. 2).

Whereas Obama's strategy placed considerable weight on "core values" as an element of national interests (The White House, 2011, pp. 5-6), Trump's placed greater emphasis on adversarial states, namely Iran (The White House, 2018). Read in conjunction with other national security documents, Trump's counterterrorism strategy shows elements of change and continuity, but it also cuts a stark contrast with the 2018 National Defense Strategy, which maintains that "inter-state strategic competition, not terrorism, is now the primary concern in US national security" (Mattis, 2018, p. 1). That document also pays homage to the importance of alliances and institutions but avoids altogether the "America First" frame. It does advocate explicitly for the construction of a more "lethal" force, however, and highlights concerns over budget discipline and affordability. It positions the (downgraded) terrorist threat amongst a wider effort to integrate a range of security concerns and policy tools. "Both revisionist powers 
and rogue regimes are competing across all dimensions of power," it states, while Iran is using "state-sponsored terrorist activities" to vie for "regional hegemony" (Mattis, 2018, p. 2).

Similarly, the administration's NSS, released in December 2017, links concerns regarding transnational terrorism to geostrategic issues involving states:

"Three main sets of challengers - the revisionist powers of China and Russia, the rogue states of Iran and North Korea, and transnational threat organizations, particularly jihadist terrorist groups - are actively competing against the United States and our allies and partners. Although differing in nature and magnitude, these rivals compete across political, economic, and military arenas, and use technology and information to accelerate these contests in order to shift regional balances of power" (The White House, 2017, p. 25).

The strategy outlined an interventionist posture that is entirely consistent with those of previous post-9/11 administrations. As with every iteration of the NSS since the Clinton administration, Trump's version foregrounds economic policy, even as it adopts a more nationalist and, at times, neo-mercantilist position. The active promotion of "American prosperity" is enumerated as a "pillar" of US strategy. "An America First National Security Strategy," it states, "appreciates that America will catalyze conditions to unleash economic success for America and the world" (The White House, 2017, p. 4). This is to be achieved through "a stable international economic system rooted in American principles of reciprocity, free markets, and free trade." (The White House, 2017, p. 17). To undercut the appeal of jihadist terrorism, the US will encourage states like Egypt and Saudi Arabia "to continue modernizing their economies" (The White House, 2017, p. 49). In the context of counterterrorism policy, the 
document emphasises shared responsibilities and the ability of partners to "work independently of US assistance" (The White House 2017, p. 11). The document calls on the US to "embrace energy dominance" while helping "allies and partners become more resilient against those that use energy to coerce" (The White House 2017, pp. 22-23). As argued in the historical materialist scholarship (Stokes \& Raphael, 2010; Wearing, 2018), by leveraging energy security at the global level, the US reinforces its structural power in international relations.

From before the onset of the War on Terror, efforts to "police the periphery" have been constitutive of a larger imperial project to coordinate power in the internationalist capitalist order. As Simon Bromley wrote in the context of debates over the Bush Doctrine, "the stability of the capitalist world depends upon the performance of certain global political functions," including "stabilising the periphery" and "combating transnational ideological challenges," so as to "uphold the common interests of different, and potentially rival, capitalist classes and states" $(2006,50)$. The precise relationship between this policing function and the inter-state system is a source of disagreement, with scholars offering competing interpretations of the nature of imperialism in the global capitalist order (Gowan, 2006; Parmar, 2018; Stokes, 2005; Thomson, 2018, pp. 16-29). Where there is consensus is that "US hegemony has played, and continues to play, a key role in bringing this order into being" (Bromley, 2006, p. 52)—and that military power is vital to the maintenance of this hegemonic arrangement. Since $9 / 11$, the exercise of military power has been organised and justified mainly through the practices and guises of counterterrorism. A recalibration towards "great powers" may be a notable development, but the explicit blending of threats from transnational terrorist groups and states is not new. Overall, these trends have little to do with Trump himself, and serve as a reminder of the structural and historical factors that impact American statecraft. 


\section{Conclusion}

Through his rhetoric, candidate Trump insisted that his presidency would lead to a fundamental change in Washington's approach to counterterrorism. As a component of his "America First" foreign policy, Trump's "hard line" approach to transnational terrorism coexisted with neoisolationist and burden-sharing appeals, with calls that partners "do more" in the fight against "Radical Islamic Extremism." Without diminishing the significance of Trump's discourse, however, it is clear that there has been considerable continuity in both the practices and functions of his administration's counterterrorism policies. Despite Trump's idiosyncratic style, he has not departed from the counterterrorism "playbook" he inherited from his predecessor. This pertains not only to the objectives of US counterterrorism efforts, it also holds true for the prominent place of counterterrorism practices within the wider goals of American statecraft.

To be sure, the transition from Obama to Trump saw some modifications in the tactical details of US counterterrorism policy. These generally tracked to Trump's more bellicose discourse. His administration widened the use of armed drones, deepened the use of SOF and expanded DOD funding for counterterrorism-related security cooperation programmes. In these respects, it has bolstered the "remote" tactics of counterterrorism that have increasingly shaped American foreign policy. In terms of the applications of US military power, the big picture has been one of continuity. Intensified campaigns against ISIS and al-Qaeda are part of a broader set of managerial practices in which the US continues to police the greater Middle East from disruptive non-state violence "from below." This suggests that, particularly in the context of the renewed focus on "revisionist" states, scholars would do well to maintain sensitivity to the means-ends calculus in analysis on change/continuity in US foreign policy. 
The lack of a fundamental shift in US counterterrorism policy suggests Trump's agential capacity to radically realign US policy is limited. By revisiting and updating the historical materialist literature on the "War on Terror," we argue that this is due in part to the structural imperatives associated with US imperialism, which, beyond simply "blocking" presidents from overhauling US policy in accordance with their own agendas, elicits interventionist policies in the global south designed to stabilise existing patterns of political-economic relations. Mediated through shifting strategies at the executive level (framed in Trump's case around his America First agenda), these structural factors continue to impact US foreign policymaking in profound ways.

\section{Bibliography}

Ashbee, E. \& S. Hurst. The Trump foreign policy record and the concept of transformational change. This volume.

Babic, M. (2020). Let't talk about the interregnum: Gramsci and the crisis of the liberal world order. International Affairs.

Biegon, R. (2017). US Power in Latin America: Renewing Hegemony. London: Routledge.

Biegon, R. (2019). A populist grand strategy? Trump and the framing of American decline. International Relations. OnlineFirst.

Blakeley, R. (2009). State terrorism and neoliberalism: The north in the south. London: Routledge.

Blakeley, R. (2018). Drones, state terrorism and international law. Critical Studies on Terrorism, 1-21.

Brands, H., \& Feaver, P. (2017). Trump and Terrorism: US Strategy after ISIS. Foreign Affairs, 96(2), 28-36.

Bromley, S. (2006). The logic of American Power in the International Capitalist Order. In A. Colas \& R. Saull (Eds.), The War on Terrorism and the American "Empire" After the Cold War (pp. 44-65). London: Routledge. 
Capaccio, A. (2020). U.S. Reaper Drone Left Soleimani With Little Chance. Bloomberg. Retrieved February 5, 2020, from https://www.bloomberg.com/news/articles/2020-0106/general-atomics-reaper-drone-left-soleimani-with-little-chance

Colás, A. (2008). Open doors and closed frontiers: The limits of American empire. European Journal of International Relations, 14(4), 619-643.

Cooper, H., Savage, C., \& Schmitt, E. (2017). Navy SEAL Killed in Somalia in First U.S. Combat Death There Since 1993. Retrieved July 16, 2019, from https://www.nytimes.com/2017/05/05/world/africa/navy-seal-killed-in-raid-against-islamicmilitants-in-somalia.html

Cox, R. W. (1981). Social forces, states and world orders: beyond international relations theory. Millennium, 10(2), 126-155.

Dombrowski, P., \& Reich, S. (2018). Beyond the tweets: President Trump's continuity in military operations. Strategic Studies Quarterly, 12(2), 56-81.

Engel, P. (2015). Donald Trump: 'I would bomb the s--- out of' ISIS. Retrieved August 11, 2018, from http://uk.businessinsider.com/donald-trump-bomb-isis-2015-11

Fermor, B. \& Holland, J. Security and polarisation in Trump's America: Securitisation and the domestic politics of threatening others. This volume.

Fielding-Smith, A., \& Purkiss, J. (2018). "Shadow wars have been accelerated and put on steroids by the Trump team." Retrieved July 16, 2019, from https://www.thebureauinvestigates.com/blog/2018-06-06/the-bureau-launches-new-projectshadow-wars

Finer, J. (2019). The Last War-and the Next? Learning the Wrong Lessons From Iraq. Foreign Affairs, 98(4), 183-191.

Geltzer, J. (2018). Trump's Counterterrorism Strategy Is a Relief. Retrieved July 16, 2019, from https://www.theatlantic.com/international/archive/2018/10/trump-counterterrorismstrategy/572170/

Goldenberg, I. \& Heras, N. (2018). Obama's ISIS policy is working for Trump. Washington Post. Retrieved September 19, 2019, from https://www.washingtonpost.com/news/posteverything/wp/2018/01/25/obamas-isis-policy-isworking-for-trump/

Goodman, C., \& Arabia, C. (2018). Major Trends in U.S. Counterterrorism Aid FY 2015-19. Retrieved July 11, 2018, from http://www.securityassistance.org/fact_sheet/major-trends-uscounterterrorism-aid-fy-2015-19

Gowan, P. (2006). The Bush turn and the Drive for Primacy. In A. Colas \& R. Saull (Eds.), The War on Terrorism and the American "Empire" After the Cold War (pp. 131-154). London: Routledge. 
Hains, T. (2015). Trump's Updated ISIS Plan: "Bomb The Shit Out Of Them," Send In Exxon To Rebuild. Retrieved July 1, 2019, from https://www.realclearpolitics.com/video/2015/11/13/trumps_updated_isis_plan_bomb_the_sh it_out_of_them_send_exxon_in_to_rebuild.html

Hassan, O. Crisis, Narratives, and the Construction of US-Middle East Relations: Continuity and Change in World History and Trump's America First. This volume.

Herbert, J., McCrisken, T., \& Wroe, A. (2019). The Ordinary Presidency of Donald J. Trump. London: Palgrave Macmillan.

Herring, E. (2013). Historical materialism. In A. Collins (Ed.), Contemporary Security Studies (pp. 42-54). Oxford: Oxford University Press.

Herring, E., \& Stokes, D. (2011). Critical realism and historical materialism as resources for critical terrorism studies. Critical Studies on Terrorism, 4(1), 5-21.

Huo, S., \& Parmar, I. (2019). 'A new type of great power relationship'? Gramsci, Kautsky and the role of the Ford Foundation's transformational elite knowledge networks in China. Review of International Political Economy, 1-24.

Ikenberry, J. (2011). Liberal Leviathan: The origins, crisis, and transformation of the American world order. New York: Princeton University Press.

Jackson, R. (2011). Culture, identity and hegemony: Continuity and (the lack of) change in US counterterrorism policy from Bush to Obama. International Politics, 48(2), 390-411.

Johnsen, G. (2019). Trump and Counterterrorism in Yemen: The First Two Years. Sana'a Center for Strategic Studies. Retrieved September 16, 2019, from https://sanaacenter.org/publications/analysis/7105

Kitchen, N. (2016). Ending “permanent war": Security and economy under Obama. In J. Holland \& M. Bentley (Eds.), The Obama Doctrine A Legacy of Continuity in US Foreign Policy? (pp. 9-25). Oxon: Routledge.

Kolko, G. (1988). Confronting the third world: United States foreign policy, 1945-1980. New York: Pantheon.

Kraft, M. B., \& Marks, E. (2017). US Counterterrorism: From Nixon to Trump-Key Challenges, Issues, and Responses. Boca Raton: CRC Press.

Krieg, A. (2016). Externalizing the burden of war: the Obama Doctrine and US foreign policy in the Middle East. International Affairs, 92(1), 97-113.

Malley, R., \& Finer, J. (2018). The Long Shadow of 9/11: How Counterterrorism Warps US Foreign Policy. Foreign Affairs, 97, 58-69.

Malone, R. (2018). Trump's First Year: Analyzing the Trump Administration's Use of Drone Strikes as a Counterterrorism Strategy in 2017. Georgetown Security Studies Review, 6(2), 618. 
Mattis, J. (2018). Summary of the 2018 National Defense Strategy of the United States of America. Retrieved September 19, 2019, from

https://dod.defense.gov/Portals/1/Documents/pubs/2018-National-Defense-Strategy-

Summary.pdf

Mcfadden, C., Arkin, W. M., \& Uehlinger, T. (2017). How the Trump Team's First Military Raid in Yemen Went Wrong. Retrieved July 16, 2019, from

https://web.archive.org/web/20171003180523/https://www.nbcnews.com/news/us-news/howtrump-team-s-first-military-raid-went-wrong-

n806246?utm_source=Sailthru\&utm_medium=email\&utm_campaign=EBB\%252010.03.201

7\&utm_term=Editorial\%2520-\%2520Military\%2520-\%2520Ea

Nussbaum, M. (2016). Trump calls for ground troops in Iraq, Syria. Retrieved July 16, 2019, from https://www.politico.com/blogs/2016-gop-primary-live-updates-and-

results/2016/03/trump-iraq-syria-220608

Parmar, I. (2018). The US-led liberal order: imperialism by another name? International Affairs, 94(1), 151-172.

Porter, P. (2018). Why America's Grand Strategy Has Not Changed: Power, Habit, and the US Foreign Policy Establishment. International Security, 42(04), 9-46.

Quinn, A. (2011). The art of declining politely: Obama's prudent presidency and the waning of American power. International Affairs, 87(4), 803-824.

Robinson, W. I. (1996). Promoting polyarchy: globalization, US intervention, and hegemony. London: Cambridge University Press.

Schmitt, E. \& Savage, C. (2019) Trump administration steps up air war in Somalia. New York Times. Retrieved September 19, 2019, https://www.nytimes.com > politics > us-somaliaairstrikes-shabab

Security Assistance Monitor. (2019). Data: 2001-2020. Retrieved July 10, 2019, from https://www.securityassistance.org/data/country/military/Coalition Support Funds/2001/2020/all/South Asia//

Authors. The Plutocrat President: Low-Conceptual Complexity and Trump's Foreign Policy. This volume.

Starr-Deelen, D. G. (2017). Counter-Terrorism from the Obama Administration to President Trump: Caught in the Fait Accompli War. London: Palgrave Macmillan.

Stokes, D. (2005). The heart of empire? Theorising US empire in an era of transnational capitalism. Third World Quarterly, 26(2), 217-236.

Stokes, D. (2009). Ideas and avocados: ontologising critical terrorism studies. International Relations, 23(1), 85-92. 
Stokes, D., \& Raphael, S. (2010). Global energy security and American hegemony. Baltimore: The Johns Hopkins University Press.

Tankel, S. (2018a). Has Trump Read His Own Counterterrorism Strategy? Retrieved July 16, 2019, from https://foreignpolicy.com/2018/10/12/has-trump-read-his-own-counterterrorismstrategy/

Tankel, S. (2018b). With us and against us: how America's partners help and hinder the war on terror. New York: Columbia University Press.

The White House. (2011). National Strategy For Counterterrorism 2011. Retrieved February 2, 2017, from https://obamawhitehouse.archives.gov/sites/default/files/counterterrorism_strategy.pdf

The White House. (2017). National Security Strategy of the United States of America, 2017. Retrieved August 11, 2018, from https://www.whitehouse.gov/wpcontent/uploads/2017/12/NSS-Final-12-18-2017-0905.pdf

The White House. (2018). National Strategy for Counterterrorism of the United States of America. Retrieved January 12, 2019, from https://www.whitehouse.gov/wpcontent/uploads/2018/10/NSCT.pdf

Thomson, A. (2018). Outsourced Empire: How Militias, Mercenaries, and Contractors Support US Statecraft. London: Pluto Press.

Tichy, L., \& Eichler, J. (2017). Terrorist Attacks on the Energy Sector: The Case of Al Qaeda and the Islamic State. Studies in Conflict \& Terrorism, 1-24.

Trump, D. (2016a). Full text: Donald Trump's speech on fighting terrorism. Retrieved July 1, 2019, from https://www.politico.com/story/2016/08/donald-trump-terrorism-speech-227025

Trump, D. (2016b). Transcript: Donald Trump's Foreign Policy Speech. Retrieved July 16, 2019, from https://www.nytimes.com/2016/04/28/us/politics/transcript-trump-foreignpolicy.html

Turse, N. (2017). American Special Operations Forces Are Deployed to 70 Percent of the World's Countries. Retrieved March 3, 2017, from https://www.thenation.com/article/american-special-forces-are-deployed-to-70-percent-ofthe-worlds-countries/

Ward, A. (2019). The US is "committed" to staying in Syria - to protect oil. Vox. Retrieved 28 Octtober, 2019, from https://www.vox.com/2019/10/25/20931932/trump-syria-oil-isiswithdrawal-troops

Watts, T., \& Biegon, R. (2017). Defining Remote Warfare: Security Cooperation. Retrieved May 11, 2018, from http://www.oxfordresearchgroup.org.uk/sites/default/files/RCPSecurity_Cooperation.pdf

Wearing, D. (2018). AngloArabia: Why Gulf Wealth Matters to Britain. London: Polity Press. 
Zenko, M. (2017). Donald Trump Is Pushing America's Special Forces Past the Breaking Point. Retrieved July 16, 2019, from https://foreignpolicy.com/2017/08/01/donald-trump-ispushing-americas-special-forces-past-the-breaking-point-jsoc-navy-seal/

${ }^{1}$ In addition to intensifying the military response to transnational terrorist organisations - this article's primary focus - the Trump administration has also securitised border control and immigration policy through the language of counterterrorism.

${ }^{2}$ In making this argument, we are not dismissing the contention developed elsewhere in this special issue that Trump is a low-complexity individual (authors, this volume). As others have argued, whilst Trump may be an extraordinary character, his presidency, in terms of both outcomes and constraints, is fairly ordinary (Herbert, McCrisken \& Wroe, 2019). The actions of the American state, with its multiple bureaucracies and agencies, are not reducible to the president alone. Certain ideas and habits persist across administrations, carried by the individuals that staff key agencies and the beliefs they hold about appropriate American foreign policy (Porter, 2018). As Porter notes from outside the historical materialist tradition, the strategy of primacy pursed by the US since 1945 has involved a focus on "creat[ing] conditions optimal for the penetration of US capital" and "priz[ing] open markets and ensur[ing]investment opportunities and access to raw materials, a pursuit of openness on American terms" (Porter, 2018, p. 20).

${ }^{3}$ As Herring notes (2013), historical materialism can be approached as a social science, a philosophy, and/or an emancipatory political project. As a social science, it is "assume[d] that fact and value (judgements of worth such as right and wrong) can be separated sufficiently to generate theoretically grounded claims that can be tested against evidence" (Herring, 2013, p. 153). 
${ }^{4}$ As illustrated by Fermor and Holland's contribution to this special issue, Gramscian concepts are not the sole preserve of historical materialist approaches. 